\title{
KUALITAS HIDUP WANITA MENOPAUSE YANG MENGGUNAKAN TERAPI SULIH HORMON DINILAI DENGAN MENQOL DI RSU PROF. DR. R. D KANDOU MANADO
}

\author{
${ }^{1}$ Sitti Qamariah \\ ${ }^{2}$ Freddy W. Wagey \\ ${ }^{3}$ Maria F. Loho
}

Bagian Obstetri dan Ginekologi RSU Prof. DR. R. D. Kandou Manado Universitas Sam Ratulangi

Email : Sitti_q@yahoo.com

\begin{abstract}
: the increasing age of the life expectancy of women led to an increased number of women in Indonesia. There is a major problem confronting the elderly woman is menopause. On menopausal women will develop a variety of complaints. Complaints arising in menopausal women is a result of lack of estrogen, the hormone treatment by administering hormone is also known as Hormone Replacement Therapy Dubbed. The above things that encourage writers to research about the quality of life of menopausal women who use Hormone Replacement Therapy Dubbed rated with MENQOL (The Menopause Specific Quality of Life Questionnaire) was General Hospital Prof. Dr. r. d. Kandou Manado. This research is a descriptive cross sectional design using a MENQOL questionnaire consists of four domains, namely vasomotor menopausal symptoms, psychosocial, physical and sexual abuse. This research was conducted on menopausal women who use hormone therapy in English was Prof. Dr. R.D. Kandou Manado in November 2012. Of the 19 Research Subjects, obtained 52,63\% experienced disruption of quality of life. Based on the symptoms, physical disorder group is the largest intrusion on the natural subjects of $84,21 \%$. There was 52,63\% of women who use Hormone Replacement Therapy in English was General Hospital Prof. Dr. R. D. Kandou Manado still experiencing disruption of quality of life based on measurement results using MENQOL.
\end{abstract}

Keywords: Quality of life, menopause, hormone replacement therapy, MENQOL

\begin{abstract}
Abstrak: Meningkatnya usia harapan hidup wanita Indonesia menyebabkan peningkatan jumlah wanita lanjut usia. Ada masalah pokok yang dihadapi wanita lanjut usia yaitu menopause. Pada wanita menopause akan timbul berbagai keluhan. Keluhan yang timbul pada wanita menopause adalah akibat dari kekurangan hormone estrogen, maka pengobatannya pun adalah dengan pemberian hormone pengganti yang dikenal dengan Terapi Sulih Hormon. Hal-hal diatas yang mendorong penulis untuk meneliti tentang kualitas hidup wanita menopause yang menggunakan Terapi Sulih Hormon dinilai dengan MENQOL (The Menopause Spesific Quality of Life Questionnaire) di RSU Prof. DR. R. D. Kandou Manado. Penelitian ini bersifat deskriptif dengan desain cross sectional menggunakan kuesioner MENQOL yang terdiri dari empat domain gejala menopause yaitu vasomotor, psikososial, fisik dan seksual. Penelitian ini dilakukan pada wanita menopause yang menggunakan terapi sulih hormon di RSU Prof. DR. R.D. Kandou Manado pada bulan November 2012. Dari 19 Subyek Penelitian, didapatkan 52,63\% mengalami gangguan kualitas hidup. Berdasarkan kelompok gejala, gangguan fisik merupakan gangguan terbanyak yang di alami subyek $84,21 \%$. Terdapat $52,63 \%$ Wanita yang menggunakan terapi sulih hormon di RSU Prof. Dr. R. D. Kandou Manado masih mengalami gangguan kualitas hidup berdasarkan hasil pengukuran menggunakan MENQOL.
\end{abstract}

Kata Kunci : Kualitas hidup, wanita menopause, Terapi Sulih Hormon, MENQOL 
Meningkatnya usia harapan hidup wanita Indonesia yang mencapai 70 tahun mulai tahun 2000 hingga kini, berdampak pada meningkatnya pula jumlah wanita lanjut usia (lansia) di Indonesia. Diharapkan bahwa para wanita lanjut usia tetap dapat menjalani "sisa" kehidupannya dengan sehat dan bahagia, bahkan tetap memiliki produktivitas yang tinggi, karena apalah artinya berumur panjang bagi seorang wanita jika harus hidup dengan berbagai macam keluhan dan menjadi beban bagi keluarganya, namun ada salah satu masalah pokok di bidang kesehatan yang dihadapi para wanita lanjut usia yaitu menopause. ${ }^{1}$

Menopause merupakan suatu bagian dari proses penuaan yang sangat alamiah, normal dan ireversibel yang melibatkan sistem reproduksi wanita. Menopause di mulai sejak 12 bulan setelah haid terakhir. Berdasarkan survei perkumpulan menopause Indonesia tahun 2005, usia menopause rata-rata wanita Indonesia $49 \pm 0,20$ tahun. $^{2}$

Pada wanita menopause akan timbul berbagai masalah kesehatan, seperti gejala vasomotorik yaitu hot flush (rasa panas dari dada hingga wajah), night sweat (keringat dimalam hari) dan mudah berkeringat, gejala psikogenik, nyeri sanggama, insomnia (susah tidur), penurunan libido, meningkatnya kejadian penyakit jantung koroner, patah tulang (osteoporosis), dementia, stroke, kanker usus besar, dan katarak. Semua masalah kesehatan tersebut berdampak terhadap penurunan kualitas hidup kaum perempuan. ${ }^{3,4}$

Gejala yang timbul pada wanita menopause merupakan akibat dari kekurangan hormone estrogen, maka pengobatannya pun dengan pemberian hormone pengganti estrogen, yang dikenal dengan istilah Terapi Pengganti Estrogen atau Estrogen Replacement Therapy ( ERT ). Biasanya pemberian estrogen ini dikombinasikan dengan progesterone sehingga dikenal sebagai
Terapi Sulih Hormon (TSH) atau Hormonal Replacement Therapy (HRT), dengan harapan dapat meningkatkan kualitas hidup wanita menopause yaitu mencegah dampak kesehatan akibat menopause tersebut, baik keluhan jangka pendek maupun jangka panjang. ${ }^{1}$

Salah satu cara yang dapat di pakai untuk menilai kualitas hidup wanita menopause yaitu dengan The Menopause-Specific Quality of Life Questionnaire (MENQOL) yang diperkenalkan pada tahun 1996 sebagai alat untuk menilai kesehatan yang berhubungan dengan kualitas hidup pada periode pasca-menopause. MENQOL terdiri dari 29 bagian dalam format skala Likert. Setiap item menilai dampak dari salah satu dari empat domain gejala menopause, seperti yang dialami selama satu bulan terakhir: vasomotor (item 1-3), psikososial (item 4-10), fisik (item 1126), dan seksual (item 27 -29). 5,6,7

Hal-hal diatas yang mendorong penulis untuk meneliti kualitas hidup wanita menopause yang menggunakan Terapi Sulih Hormon (TSH) yang di nilai dengan MENQOL pada wanita menopause di RSUP Prof. Dr. R. D. Kandou Manado.

\section{Rumusan Masalah}

Bagaimana kualitas hidup wanita menopause yang menggunakan Terapi Sulih Hormon (TSH) yang dinilai dengan MENQOL pada wanita menopause di RSU Prof. Dr. R. D. Kandou Manado ?

\section{Manfaat Penelitian}

- Diharapkan dapat memberikan gambaran tentang bagaimana kualitas hidup wanita menopause yang menggunakan TSH

- Manfaat untuk penulis, yaitu memperluas wawasan penulis dan mengasah kemampuan penulis dalam pembuatan penelitian ilmiah

- Untuk membantu penelitian lebih lanjut. 


\section{METODE}

Jenis penelitian ini merupakan Penelitian deskriptif dengan pendekatan desain cross sectional. Tempat penelitian di RSU Prof. Dr. R. D. Kandou Manado. Penelitian ini dilakukan pada bulan November 2012 - Januari 2013. Sampel dalam penelitian ini yaitu wanita yang telah menopause dan berusia 45 - 59 tahun yang menggunakan Terapi Sulih Hormon di RSUP Prof. Dr. R. D. Kandou Manado

\section{Batasan Operasional}

- Kualitas Hidup: penilaian individu terhadap posisi mereka di dalam kehidupan, dalam konteks budaya dan sistem nilai dimana mereka hidup dalam kaitannya dengan tujuan individu, harapan, standar serta apa yang menjadi perhatian individu. ${ }^{7}$

- Menopause: Menopause didefinisikan oleh WHO sebagai penghentian menstruasi secara permanen akibat hilangnya aktivitas folikular ovarium. $^{10}$

- Wanita Menopause: wanita yang telah memasuki usia tengah baya mengalami proses biologis yaitu masa menopause yang ditandai dengan berhentinya haid lebih dari satu tahun. ${ }^{7}$

- TSH: Hormone Replacement Therapy $(H R T)$ atau yang diterjemahkan sebagai Terapi Sulih Hormon (TSH) adalah suatu terapi menggunakan hormon yang diberikan untuk mengurangi efek defisiensi hormon. ${ }^{1}$

- Angeliq: preparat Terapi Sulih Hormon (TSH) kombinasi Drospirenon 2,0 $\mathrm{mg}$ dan Estradiol 1,0 mg yang di berikan secara oral dengan dosis $1 \times 1$ tablet/hari selama 6 bulan. ${ }^{9}$
- MENQOL : alat/skala ukur untuk menilai kesehatan yang berhubungan dengan kualitas hidup pada periode pasca-menopause. terdiri dari 29 item. Setiap item menilai dampak dari salah satu dari empat domain gejala menopause, seperti yang dialami selama satu bulan terakhir: vasomotor (item 1-3), psikososial (item 4-10), fisik (item 11-26), dan seksual (item 27 $-29) .5,6$

\section{Instrument Penelitian}

Informed Consent and The MenopauseSpecific Quality of Life Questionnaire (MENQOL)

\section{Pengumpulan Data}

- Membagikan kuesioner kepada wanita yang telah menopause dan berusia $45-$ 59 tahun yang telah menggunakan TSH di RSU Prof. Dr. R. D. Kandou Manado

- Kuesioner diisi oleh para wanita sebagai subjek penelitian dengan penjelasan terlebih dahulu oleh penulis, mengenai cara pengisian kuesioner, sesuai dengan maksud penelitian

\section{Pengolahan dan Analisis Data}

- Data yang diperoleh diolah menggunakan sistem tabulasi dan presentasi

- Analisis data menggunakan statistik deskriptif

\section{HASIL PENELITIAN}

Berikut ini merupakan hasil penelitian yang diperoleh dari 19 subyek penelitian

\section{Krakteristik Sosiodemografik}

Tabel 1. Karakteristik sosiodemografik subyek antara lain kelompok umur, suku bangsa, status pernikahan, pendidikan, pekerjaan, dan aktivitas tambahan di luar pekerjaan.

\begin{tabular}{lcc}
\hline \multicolumn{1}{c}{ Aspek Sosiodemografik } & n & \% \\
\hline Kelompok umur & 1 & \\
$45-49$ & 12 & 5,3 \\
$50-54$ & & 63,2 \\
\hline
\end{tabular}




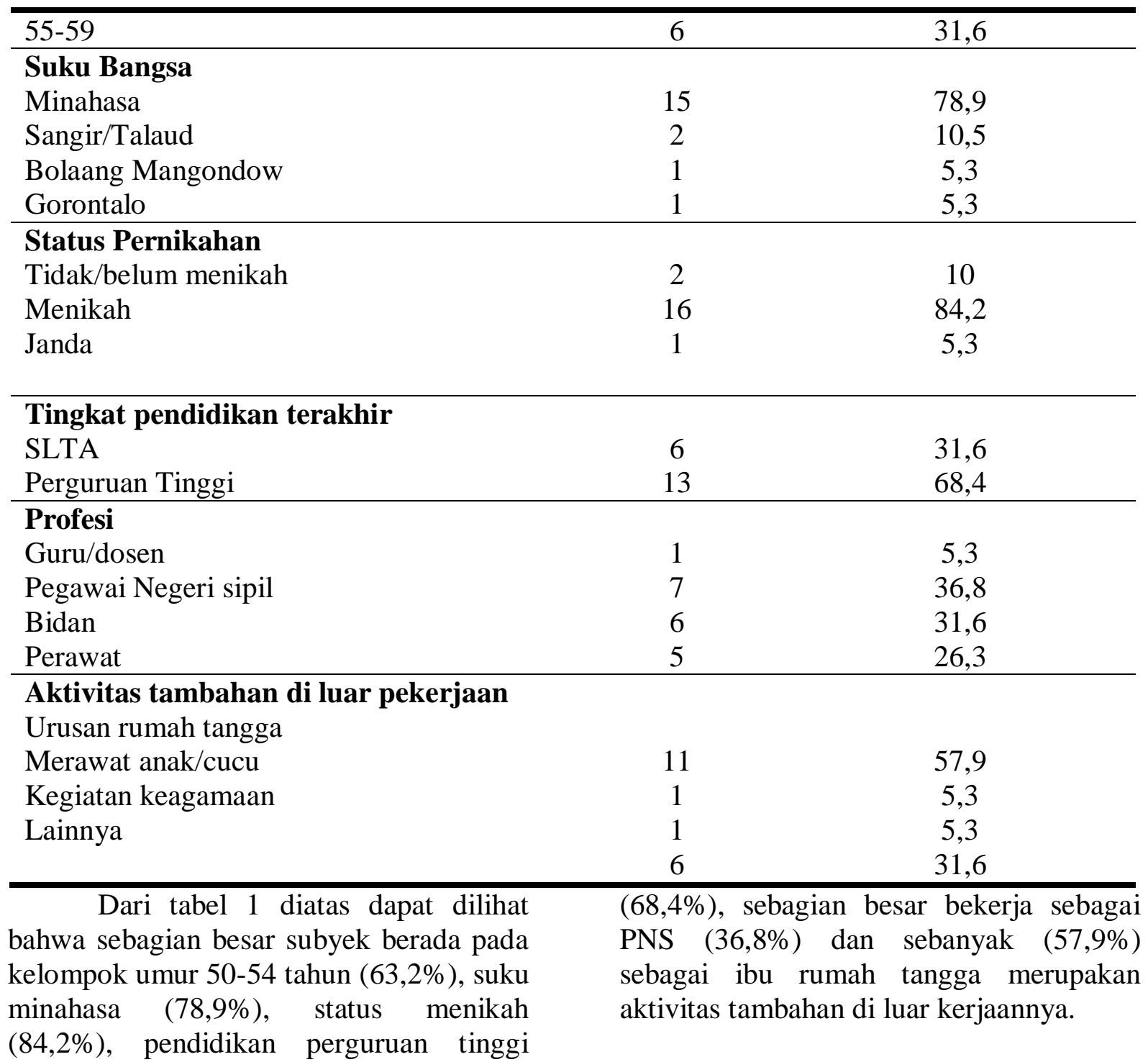

Kualitas Hidup Wanita Menopause

Tabel 2. Aspek dan derajat gangguan kualitas hidup subyek

\begin{tabular}{|c|c|c|c|c|c|c|c|c|c|c|}
\hline \multirow{4}{*}{$\begin{array}{c}\text { ASPEK } \\
\text { GANGGUA } \\
\mathbf{N}\end{array}$} & \multirow{3}{*}{\multicolumn{2}{|c|}{$\begin{array}{c}\text { TIDAK } \\
\text { ADA } \\
\text { KELUHAN }\end{array}$}} & \multicolumn{8}{|c|}{ TINGKAT GANGGUAN KUALITAS HIDUP } \\
\hline & & & \multicolumn{8}{|c|}{ ADA KELUHAN } \\
\hline & & & \multicolumn{2}{|c|}{ Ringan } & \multicolumn{2}{|c|}{ Sedang } & \multicolumn{2}{|c|}{ Berat } & \multicolumn{2}{|c|}{ Sangat berat } \\
\hline & $\mathbf{n}$ & $\%$ & $\mathbf{n}$ & $\%$ & $\mathbf{n}$ & $\%$ & $\mathbf{n}$ & $\%$ & $\mathbf{n}$ & $\%$ \\
\hline Vasomotor & 10 & 52,63 & 7 & 36,84 & 2 & 10,52 & - & - & - & - \\
\hline Psikososial & 8 & 42,10 & 10 & 52,63 & 1 & 5,26 & - & - & - & - \\
\hline Fisik & 3 & 15,78 & 10 & 52,63 & 6 & 31,57 & - & - & - & - \\
\hline Seksual & 9 & 47,36 & 8 & 42,10 & 2 & 10,52 & - & - & - & - \\
\hline
\end{tabular}

Dari tabel 2 diatas, di tinjau dari aspek gangguan yang di alami subyek, gangguan fisik merupakan gangguan yang terbanyak di alami subyek (16 subyek atau
$84,21 \%), 52,63 \%$ diantaranya mengalami gangguan tingkat ringan. Gejala psikososial juga di alami lebih dari separuh jumlah subyek yaitu 11 subyek atau 
$57,89 \%$ dan 10 subyek atau 52,63\% mengalami gangguan tingkat ringan. Gejala seksual di alami oleh 10 subyek atau $52,63 \%, \quad 42,10 \%$ diantaranya mengalami gangguan tingkat ringan, sedangkan gejala vasomotor sebanyak 10 subyek atau $52,63 \%$ tidak mengalami gangguan vasomotor dan 36,84\% mengalami gangguan pada tingkat ringan. Dari semua aspek gangguan diatas tidak ada subyek yang mengalami gangguan kualitas hidup pada tingkatan berat dan sangat berat.

Tabel 3. Gejala menopause menurut MENQOL di RSU Prof. DR R. D. Kandou Manado

\begin{tabular}{|c|c|c|c|c|}
\hline Gejala & $\begin{array}{c}\text { Tidak } \\
\text { Ada } \\
\text { Keluhan }\end{array}$ & $\%$ & Keluhan & $\%$ \\
\hline \multicolumn{5}{|l|}{ Vasomotor } \\
\hline $\begin{array}{l}\text { Gejolak panas pada daerah muka sampai } \\
\text { leher }\end{array}$ & 16 & 84,21 & 3 & 15,8 \\
\hline Keringat Malam & 15 & 78,9 & 4 & 21,1 \\
\hline Mudah berkeringat & 11 & 57,9 & 8 & 42,1 \\
\hline \multicolumn{5}{|l|}{ Psikososial } \\
\hline Merasa tidak puas dengan kehidupan pribadi & 18 & 94,7 & 1 & 5,3 \\
\hline Merasa cemas atau bingung & 17 & 89,5 & 2 & 10,5 \\
\hline Mengalami penurunan daya ingat & 10 & 52,6 & 9 & 47,4 \\
\hline $\begin{array}{l}\text { Merasa ketrampilan menurun \& berkurang } \\
\text { dari biasa }\end{array}$ & 11 & 57,9 & 8 & 42,1 \\
\hline Merasa depresi atau cepat sedih & 18 & 94,7 & 1 & 5,3 \\
\hline Merasa kurang sabar terhadap orang lain & 12 & 63,2 & 7 & 36,8 \\
\hline Keinginan untuk menyendiri & 19 & 100 & 0 & 0 \\
\hline \multicolumn{5}{|l|}{ Fisik } \\
\hline Sendawa atau sering buang angin (kembung) & 14 & 73,7 & 5 & 26,3 \\
\hline Nyeri otot dan sendi & 9 & 47,4 & 10 & 52,6 \\
\hline Merasa cepat lelah dan lemah & 9 & 47,4 & 10 & 52,6 \\
\hline Sulit tidur & 11 & 57,9 & 8 & 42,1 \\
\hline Sakit pada punggung leher atau kepala & 10 & 52,6 & 9 & 47,4 \\
\hline Kemampuan fisik berkurang & 9 & 47,4 & 10 & 52,6 \\
\hline Penurunan stamina & 8 & 42,1 & 11 & 57,9 \\
\hline Merasa kurang bertenaga & 13 & 68,4 & 6 & 31,6 \\
\hline Kulit kering & 13 & 68,4 & 6 & 31,6 \\
\hline Berat badan bertambah & 9 & 47,4 & 10 & 52,6 \\
\hline Rambut wajah bertambah & 17 & 89,5 & 2 & 10,5 \\
\hline $\begin{array}{l}\text { Perubahan pada penampilan, corak atau } \\
\text { warna kulit }\end{array}$ & 11 & 57,9 & 8 & 42,1 \\
\hline Merasa tubuh membengkak & 15 & 78,9 & 4 & 21,1 \\
\hline Sakit punggung bagian bawah & 12 & 63,2 & 7 & 36,8 \\
\hline Sering buang air kecil & 14 & 73,7 & 5 & 26,3 \\
\hline $\begin{array}{l}\text { Buang air kecil teidak tertahan saat tertawa } \\
\text { atau batuk }\end{array}$ & 12 & 63,2 & 7 & 36,8 \\
\hline \multicolumn{5}{|l|}{ Seksual } \\
\hline Penurunan dalam keinginan seksual & 10 & 52,6 & 9 & 47,4 \\
\hline Vagina kering sewaktu bersetubuh & 11 & 57,90 & 8 & 42,1 \\
\hline Menghindar dari hubungan intim & 11 & 57,90 & 8 & 42,1 \\
\hline
\end{tabular}


Dari tabel 3 diatas dapat dilihat pada gejala vasomotor terdapat 16 subyek dari 19 subyek $(84,21 \%)$ tidak mengalami keluhan gejolak panas pada daerah muka sampai leher. Terdapat 19 subyek dari 19 subyek $(100 \%)$ tidak mengalami keinginan untuk menyendiri, 17 subyek dari 19 subyek $(89,5 \%)$ tidak mengalami keluhan rambut wajah bertambah dan 11 dari 19 subyek $(57,9 \%)$ tidak mengalami keluhan vagina kering sewaktu bersetubuh dan menghindar dari hubungan intim.

\section{PEMBAHASAN}

Dari hasil penilaian kualitas hidup pada 19 subyek wanita menopause yang menggunakan terapi sulih hormon yang di nilai berdasarkan menopause specific quality of life questionnaire (MENQOL), didapatkan $47,36 \%$ tidak mengalami gangguan dan 52,63\% mengalami gangguan. Yang mengalami gangguanpun sebagian besar berada pada tingkatan ringan dan sebagian kecil pada tingkatan sedang. Tidak ada subyek yang mengalami gangguan pada tingkatan berat dan sangat berat.

Di tinjau dari aspek gangguan setelah penggunaan terapi sulih hormon, pada gangguan vasomotor terdapat lebih banyak subyek yang tidak mengalami gangguan dibandingkan dengan yang mengalami gangguan yaitu pada gangguan vasomotor sebanyak $84,21 \%$ tidak mengalami gejolak panas pada daerah muka sampai leher (hot flash) dan yang mengalami gangguan sebanyak $15,8 \%$. Pada penelitian lain di Australia dan New Zealand juga mendapatkan hasil yang sama atau bermakna yaitu sebanyak $78 \%$ dari 148 sampel tidak mengalami keluhan hot flash setelah menggunakan terapi sulih hormone. ${ }^{10}$ Ada juga hasil Meta-analisa yang dilakukan oleh Mac Lennan dkk pada akhir studi terdapat penurunan frekuensi hot flush yang signifikan yaitu $50.8 \%$ pada kelompok terapi dibandingkan dengan data sebelum penggunaan terapi sulih hormon yaitu $95 \% .{ }^{10}$ Pada dasarnya penyebab hot flash masih belum diketahui namun diduga berhubungan dengan keadaan defisiensi estrogen karena memberikan efek yang baik setelah pemberian terapi sulih hormon. Pada penelitian lain juga diduga hot flash karena adanya mekanisme yang berhubungan dengan penurunan kadar katekolamin hipotalamus dan labilnya pusat termoregulator tubuh di hipotalamus yang diinduksi oleh penurunan kadar estrogen dan progesteron. ${ }^{11}$ Wanita menopause pada penelitian ini yang telah menggunakan terapi sulih hormon sebagian besar merasa tidak ada gangguan vasomotor terutama hot flash dan sebagian kecil yang mengalami gangguan ini pun berada pada tingkat ringan.

Ditinjau dari aspek gangguan yang di alami subyek, pada gangguan psikososial, sebanyak 19 subyek (100\%) tidak mengalami keinginan untuk menyendiri namun jika dilihat secara menyeluruh dari beberapa keluhan psikososial, terdapat 52,63\% subyek yang mengalami gangguan psikososial namun pada tingkatan ringan. Hasil yang di dapatkan kurang bermakna namun dari ringannya gejala yang dialami maka dapat dinilai bahwa psikososialnya berada pada tingkatan yang baik karena mereka dapat melakukan aktifitas sehari-hari mereka tanpa ada perasaan terbeban karena ketidakstabilan emosionalnya dan itu berarti kualitas hidupnya juga baik. Pada penelitian lain di Australia dan New zealand juga mendapatkan hasil serupa yang menunjukkan hasil yang kurang bermakna.

Dilihat dari aspek gangguan fisik secara menyeluruh, sebanyak 10 subyek atau 52,63\% yang mengalami keluhan pada tingkatan ringan dan 6 subyek atau 31,57\% pada tingkatan sedang dan 3 subyek atau $15,78 \%$ tidak mengalami gangguan fisik. Namun dilihat dari tingkatan gangguan fisik yang sebagian besar pada tingkatan yang ringan dan dari keterangan yang didapatkan oleh peneliti dari para subyek yaitu gejala tersebut tidak mengganggu aktifitas mereka sehari-hari maka hasil tersebut dapat disimpulkan bahwa dengan tidak terganggunya aktifitas sehari-hari mereka karena gejala tersebut berarti kualitas hidupnya dalam tingkatan baik. 
Dari aspek gangguan seksual setalah penggunaan terapi sulih hormon, 11 subyek dari 19 subyek atau 57,90\% tidak mengeluhkan vagina kering ketika bersetubuh dan menghindari hubungan intim, selebihnya mengalami gejala ini. Pada penelitian lain yang dilakukan terhadap 1006 wanita postmenopause awal yang berumur antara 48-58 tahun. Dari hasil penelitiannya terdapat $15 \%$ wanita yang mengalami keluhan dan lainnya tidak mengalami keluhan tersebut. ${ }^{12}$ Presentase subyek antara yang mengalami keluhan dan yang tidak mengalami keluhan setelah menggunakan terapi sulih hormon menunjukkan perbedaan yang tidak terlalu bermakna, menurut peneliti hal ini mungkin dipengaruhi oleh sedikitnya sampel pada penelitian ini, hal ini dapat kita lihat dari perbedaan hasil yang di dapatkan oleh peneliti dengan jumlah sampel sedikit dan hasil yang didapatkan pada penelitian lain dengan jumlah sampel yang lebih banyak. Dari hasil yang di dapatkan oleh peneliti yaitu berkurangnya keluhan dan ringannya gejala seksual pada wanita sebagai subyek penelitian ini mungkin dipengaruhi oleh efek dari terapi sulih hormon yang mereka gunakan.

Hasil penelitian lain dalam pembahasan yang telah di bandingkan dengan hasil penelitian yang di lakukan di RSUP Prof. Dr. R. D. Kandou Manado ini tidak memfokuskan pada tingkatan kualitas hidup secara kesluruhan sehingga tidak didapati hasil derajat gangguan kualitas hidup.

\section{Kesimpulan}

Dari hasil penelitian dan pembahasan di atas maka dapat di ambil kesimpulan : $52,63 \%$ wanita yang menggunakan terapi sulih hormon di RSU Prof. Dr. R. D. Kandou Manado masih mengalami gangguan kualitas hidup. Gangguan fisik merupakan gangguan terbanyak yang di alami subyek yang telah menggunakan terapi sulih hormon (16 subyek atau $84,21 \%$ ). Secara keseluruhan wanita menopuase yang menggunakan terapi sulih hormon dalam penelitian ini mempunyai kualitas hidup yang baik.

\section{UCAPAN TERIMA KASIH}

Dengan penuh kerendahan hati dan rasa hormat, penulis ingin menyampaikan ucapan terima kasih yang sedalamdalamnya kepada :

1. dr. Jioce J. Kaeng, $\operatorname{SpOG}(\mathrm{K})$ dan dr. Ruddy A. Lengkong, SpOG(K), selaku Dosen Penguji yang telah berkenan hadir dan memberikan kritik, saran serta masukan yang membangun dalam penyusunan Karya Tulis Ilmiah ini.

2. Dr. Feeter Suryanto yang telah memberikan masukan dalam penyusunan Karya Tulis Ilmiah ini.

3. Semua pihak yang telah berperan dan membantu penulis dalam penyelesaian Karya Tulis Ilmiah ini yang tidak dapat disebutkan satu per satu.

\section{DAFTAR PUSTAKA}

1. Wratsangka R. Pemberian terapi sulih hormone sebagai upaya meningkatkan kesehatan wanita menopause. $J$ Kedokteran Trisakti 1999;18(3):155162.

2. Soewondo P. Menopause, andropause dan somatopause perubahan hormonal pada proses menua. Dalam : Sudoyo AW, Setiohadi B, Alwi I, Simadibrata M, Setiati S, Editor. Buku ajar ilmu penyakit dalam. Edisi V. Jakarta : Pusat Penerbitan Ilmu Penyakit Dalam Fakultas Kedokteran Indonesia; 2009.h 2078-82.

3. Baziaad A. Sulih Hormon(HRT): Sebuah Persimpangan antara Harapan dan Realita. Departemen Obstetri dan Ginekologi Fakultas Kedokteran Universitas Indonesia, RS Cipto Mangunkusuma Jakarta; 2008.h 161-6

4. Proverawati A, Sulistyawati E. Menopause dan Sindrome Premenopause, Yogyakarta: Nuha Medika 2010

5. Radtke IV, Terhorst L, Cohen SM. The Menopause-Specific Quality of Life (MENQOL) 
Psychometric Evaluation among Breast Cancer Survivors. NIH Public Access Author Manuscript. 2011.h 289-295.

6. Dole KBV. Dissertation : The Evaluation of the menopause-specific quality of life Questonnaire and association of vasomotor and psychosocial symptoms among postmenopausal women in the united states. University of North Carolina at Chapel Hill. 2009.

7. Larasati T. Jurnal kualitas hidup pada wanita yang sudah memasuki masa menopause. Fakultas Psikologi Universitas Gunadarma 2009.

http://www.gunadarma.ac.id/library/arti cles/graduate/psychology/2009/artikel 10504129.pdf

8. Brashers V. Aplikasi Klinis Patofisiologi pemeriksaan \& Manajemen. Edisi 2. Jakarta: EGC; 2007.h 363.

9. Suryanto .F, Loho M.F.T, Wagey .F. Penelitian : Pengaruh pemberian terapi sulih hormon terhadap profil lipid wanita menopause di blu RSU Prof. Dr. R.D. Kandou. Kedokteran Universitas Sam Ratulangi.

10. Welton AJ, Vickers MR, Kim J, Ford D, Lawton BA, MacLennan AH, dkk. Healt related quality of life combined hormone replacement therapy : randomized trial ; british medical journal, 22 august 2008.

11. Sawitri EI, Fauzi N, Widyani R. kulit dan menopause-menifestasi dan penatalaksanaan. J. Kedokteran Universitas Airlangga Surabaya. http://journal.unair.ac.id/filerPDF/Men opause\%20Vol\%2021\%20No\%201.pdf

12. Anonim. Terapi Sulih Hormon pada Wanita Perimenopause. HTA Indonesia, 2004, h 2/39. 